\title{
Improving the efficiency of power boilers by cooling the flue gases to the lowest possible temperature under the conditions of safe operation of reinforced concrete and brick chimneys of power plants
}

\author{
Evgeny Ibragimov ${ }^{1, *}$, and Sergei Cherkasov ${ }^{2}$ \\ ${ }^{1}$ Ufa State Aviation Technical University, Department of aviation heat engineering and heat power \\ engineering, Karl Marx street 12, city Ufa, Republic of Bashkortostan, 450008, Russian Federation \\ ${ }^{2}$ Salavat thermal power plant LLC "Bashkir generating company", Management, mailbox №20, city \\ Salavat, Republic of Bashkortostan, 453256, Russian Federation
}

\begin{abstract}
The article presents data on the calculated values of improving the efficiency of fuel use at the thermal power plant as a result of the introduction of a technical solution for cooling the flue gases of boilers to the lowest possible temperature under the conditions of safe operation of reinforced concrete and brick chimneys with a constant value of the flue gas temperature, when changing the operating mode of the boiler.
\end{abstract}

\section{Introduction}

In accordance with the Decree of the government of the Russian Federation dated 07.12.2015 №1339 "on amendments to the state program of the Russian Federation "energy Efficiency and energy development" the expected result of the implementation is "to limit the growth of tariffs on the basis of improving the economic and energy efficiency of the industry, reducing the specific fuel consumption $\mathrm{t} / \mathrm{kWh}$ in 2020" [1].

One of the effective measures to reduce the amount of specific fuel consumption for electricity supply at power plants by $0.7-2.98 \mathrm{~g} / \mathrm{kWh}$ is the modernization of regenerative air heaters (RVP) of power boilers, which allows to increase the efficiency of "gross" boilers by reducing the temperature of flue gases leaving [2].

The magnitude of the effect of modernization RVP boilers varies widely, because it depends significantly on the source of the technical condition of the modernized sun and used for the modernization of the packing. For example, as a result of the work on the modernization of the RVP, the value of reducing the temperature of the exhaust gases is for boilers PK-41 with RVP-4, BKZ-320-140 with RVP-51, BKZ-420-140 with RVP-54, TGM84 with RVP-54 value from 4 to 17 degrees $[2,3]$ (a smaller value of temperature reduction corresponds to the results of the modernization of the boiler with RVP, which is in the original good technical condition before the modernization). Design value flue gas temperature for

*Corresponding author: ibragimoves5757@ mail.ru 
boilers with no upgraded sun are in the range of $130-142{ }^{\circ} \mathrm{C}$. In particular, in accordance with the typical energy characteristics of the boiler type TGMP-114 when working with nonupgraded RP, which are in good technical condition, the temperature of the exhaust gases at rated load is $130^{\circ} \mathrm{C}$ [4]. According to the specifications made now modern utility boilers flue gas temperature of boilers, for example, of the type PP-1000-255, PP-2650-255 GMN is 134 0C, type PP-3950-255 GM is $142{ }^{\circ} \mathrm{C}$ [5]. Thus, the temperature of the leaving gases at nominal load when working on gas fuel as a result of modernization of the RVP of the boilers which are in operation can be lowered as much as possible approximately to the level of 126 $-138{ }^{\circ} \mathrm{C}$. In this regard, even after the implementation of measures to improve the technical characteristics of the existing RVP by upgrading their packing, there is a significant energy saving potential associated with a further decrease in the temperature of the outgoing gases, both now in operation of boilers and newly produced by the industry. In order to use the available energy-saving potential, it is not enough to carry out works on modernization of existing air heaters and additional reconstruction of the boiler with the installation of an additional heat exchanger after the existing air heaters of boilers is necessary. At the same time, the limit value of possible decrease in temperature of the leaving gases of the boilers operated at power plants is limited to requirements of ensuring long, safe operation of reinforced concrete and brick chimneys and shall be not less than $100{ }^{\circ} \mathrm{C}[6]$.

Known technical solutions for the installation of additional contact heat exchangers to provide significant cooling of the flue gases of boilers [7]. Depending on the temperature of the source water sent to the contact heat exchanger, the temperature of the exhaust gases at the outlet of the contact heat exchanger can reach $44{ }^{\circ} \mathrm{C}$. In the USSR in the 1980 s were released standard designs of boilers using contact heat exchangers. In total, several hundred pieces of contact heat exchangers for boilers providing hot water and heating load were manufactured and installed in the country [7].

But the introduction of this technical solution at thermal power plants did not happen. The main reasons limiting the possibility of their use in power plants were: lowering the temperature of flue gases after the contact heat exchangers located in the gas flues of boilers below the permissible requirements [6], which required the use of various expensive technical solutions to protect the flues of boilers and chimneys from corrosion; the practical impossibility of using such heat exchangers when working on fuel oil; the need to ensure an increase in the $\mathrm{pH}$ of the heated water in the heat exchanger after its contact with the flue gases; the need to equip the boiler flue gas drainage system of flue gas condensate and address the issue of its further utilization; changes in the size of the sanitary protection zone due to the deterioration of dispersion due to a significant decrease in the flue gas temperature.

\section{Methods}

For boilers of power plants more preferable is another technical solution, in which to exclude the formation of condensate in the existing flues of the boiler after cooling the flue gases below the dew point, their cooling is carried out in the newly installed recuperative heat exchanger, which is located in the newly constructed additional flue gas, parallel to the existing flues of the boiler. Selection of flue gases from the existing flue to the newly installed heat exchanger and their return back to the existing flue gas, followed by mixing with the main flue gas flow is made at the expense of the newly installed additional smoke exhauster. The additional flue consists of a descending part to the newly installed chimney and a heat exchanger installed at the zero point and an ascending part of the newly installed flue to return the flue gas taken to the heat exchanger to the existing boiler flue. To be able to provide the required temperature of the flue gases in front of the chimney at any load of the boiler, the flow of flue gases, selected for the newly installed heat exchanger, is changed by changing the performance of the newly installed smoke exhauster, by applying an adjustable drive of 
its electric motor. The condensate formed at the zero point from the flue gases after the heat exchanger is discharged into the newly mounted tank, from where, with the help of a newly installed pump, it is sent to the newly mounted decarbonizer to remove the carbon dioxide and oxygen absorbed by the condensate from the flue gases. It is possible to use different types of decarbonizers, for example, according to the data given in [7] the gases absorbed by the condensate can be removed by means of a deaerator, while the $\mathrm{pH}$ of the condensate is about $7-7,5$. In the presence in the chemical shop of the condensate treatment plant, the temperature of the formed condensate of flue gases allows it to be directed to the condensate treatment without additional cooling. The additional heat exchanger is made of corrosionresistant material (e.g. stainless steel), heat-insulated and can be placed outdoors. The newly installed exhaust and ascending flues, as well as the section of the existing boiler flue at a distance of several meters after mixing with the "cold" flue gases returned to the main flue, should be protected from corrosion, for example, by applying an anti-corrosion coating. When condensate is formed in the flue gas mixing zone in the existing boiler flue, it is discharged into the previously mentioned newly installed flue gas condensate collection tank. When transferring the boiler to the combustion of fuel oil (or a mixture of gas and fuel oil), additional gas flues of the boiler are disconnected from the main gas flue by means of newly mounted gate valves.

\section{Results and discussion}

Of interest is the numerical value of the increase in the level of energy efficiency in the implementation of the considered technical solution at the power plant. The efficiency calculation is carried out on the example of a power plant with boilers TGM-151 and steam turbines PT 60-90/13. As initial data for calculation are accepted:

- the newly installed additional flue gas with heat exchangers installed in them is connected to the existing common flue gas outlet of the flue gas to one of the flue pipes of the power plant from several boilers connected to it, so one of the boilers is constantly in operation;

- as the cooling medium of the newly installed heat exchanger, water from the surface source is used, the average annual temperature of which is $10{ }^{\circ} \mathrm{C}$;

- condensing economizers with a heat capacity of about $1.5 \mathrm{Gcal} / \mathrm{h}$, developed in JSC "Prom-engineering", are used as a heat exchanger [8];

- in total, two heat exchangers are mounted in the flue in parallel, since the thermal power of one heat exchanger, as it was revealed as a result of the calculations, is sufficient to cool the flue gases after mixing only up to $122^{\circ} \mathrm{C}$;

- the condensate of flue gases after decarbonization is discharged to the condensate treatment of the chemical shop of the station;

- the average annual temperature of exhaust gases after the boiler at the entrance to the newly installed heat exchangers is $142^{\circ} \mathrm{C}$ at a boiler load of $155 \mathrm{t} / \mathrm{h}$;

- the temperature of flue gases in front of the chimney should be about $100{ }^{\circ} \mathrm{C}$;

- the excess air in the regime section of the boiler is 1.1 ;

- the suckers in the convective part of the boiler are $36 \%$;

- fuel consumption per boiler 15.1 t. u. t./h;

- boiler efficiency "gross" on the reverse balance 91,47\%;

- efficiency of heat exchangers $98 \%$;

- rate of flue gases discharged to the newly mounted additional flue on both of the heat exchanger is to 89.2 thousand cubic meters. $\mathrm{m} / \mathrm{h}$;

- the total flow rate of water heated in heat exchangers is $80 \mathrm{t} / \mathrm{h}$;

- heat release for heating the network water is made from the heat removal of turbines; 
- heating of water in the newly installed heat exchangers leads to the unloading of the heat removal of the turbines of the station, which leads to an increase in the share of condensation generation to maintain the same value of the electric power of the turbines. The specific consumption of conventional fuel for the supply of electric energy in the condensation mode of operation is $428.6 \mathrm{~g} / \mathrm{kWh}$, and at the heating $303.7 \mathrm{~g} / \mathrm{kWh}$;

- the cost of conventional fuel 3980 rubles. per ton of conventional fuel (t. u. t.);

- the cost of electricity for own needs 1.1 rubles / $\mathrm{kWh}$;

- specific consumption of conventional fuel for the release of thermal energy of the power plant $141.9 \mathrm{~kg} / \mathrm{Gcal}$;

- the power of the newly installed smoke exhauster, pumps for pumping cooling water, drainage of the resulting condensate is a total of $88 \mathrm{~kW}$.

The results of the calculation of the effectiveness of the considered technical solution performed in accordance with $[9,10]$ are given in table. 1 .

Table 1. The results of the calculation of the efficiency of the installation of additional flue

connected in parallel to the existing flues of boilers with heat exchangers for cooling flue gas

\begin{tabular}{|c|c|c|}
\hline № & Name & $\begin{array}{l}\text { Numerical } \\
\text { value }\end{array}$ \\
\hline 1 & The temperature of the cooling water after heat exchangers, ${ }^{0} \mathrm{C}$ & 42 \\
\hline 2 & Flue gas temperature after heat exchangers, ${ }^{0} \mathrm{C}$ & 53 \\
\hline 3 & $\begin{array}{l}\text { The flow rate of the flue gas at each of the two heat exchangers, } \\
\text { thousand cubic meters / h }\end{array}$ & 44,6 \\
\hline 4 & $\begin{array}{l}\text { The flow rate of the flue gas behind the boiler to the selection of } \\
\text { the heat exchanger, cubic meters/h }\end{array}$ & 198 \\
\hline 5 & $\begin{array}{l}\text { The proportion of flow of the flue gases discharged to the heat } \\
\text { exchanger, the total flow of flue gases }\end{array}$ & 0,45 \\
\hline 6 & $\begin{array}{l}\text { The temperature of the flue gases in the flues after mixing with the } \\
\text { flue gas, }{ }^{0} \mathrm{C}\end{array}$ & 102 \\
\hline 7 & $\begin{array}{l}\text { Change of thermal energy in flue gases at change of their } \\
\text { temperature from } 142{ }^{0} \mathrm{C} \text { to } 102{ }^{0} \mathrm{C} \text { at the considered mode of } \\
\text { operation of the boiler, Gcal / } \mathrm{h}\end{array}$ & 2,87 \\
\hline 8 & $\begin{array}{l}\text { Increasing the efficiency of the "gross" boiler with a decrease in } \\
\text { the temperature of the exhaust gases, } \%\end{array}$ & 2,3 \\
\hline 9 & $\begin{array}{l}\text { Reduction of flue gas temperature due to partial utilization of their } \\
\text { heat, }{ }^{0} \mathrm{C}\end{array}$ & 40 \\
\hline 10 & $\begin{array}{l}\text { Heat energy consumption for water heating in additional heat } \\
\text { exchangers, Gcal } / \mathrm{h}\end{array}$ & 2,72 \\
\hline 11 & $\begin{array}{l}\text { Fuel economy at the expense of partial use of heat of leaving gases } \\
\text { for a year of work, t. u. } t \text { (thousand rubles) }\end{array}$ & $3381(13456)$ \\
\hline 12 & $\begin{array}{l}\text { Reduction of the heating capacity of the turbines PT } 60-90 / 13 \text { due } \\
\text { to the reduction of heat release from the heat selection in the } \\
\text { replacement of heat release with selected steam partial heat } \\
\text { recovery of flue gases, MW }\end{array}$ & 1,1 \\
\hline 13 & $\begin{array}{l}\text { The increase in fuel consumption and costs for the year of operation } \\
\text { when replacing the heating capacity of the turbines with } \\
\text { condensation power to ensure a constant value of the total electric } \\
\text { power of the turbines, t. u. } t \text { (thousand rubles) }\end{array}$ & $1204(4791)$ \\
\hline 14 & $\begin{array}{l}\text { Consumption of condensate formed during cooling of flue gases in } \\
\text { heat exchangers, } \mathrm{t} / \mathrm{h}\end{array}$ & 3,5 \\
\hline
\end{tabular}




\begin{tabular}{|c|l|c|}
\hline 15 & $\begin{array}{l}\text { Additional income for the year of work from reduction of costs for } \\
\text { preparation of the chemically treated water at use in the cycle of } \\
\text { station of the condensate formed from flue gases, thousand rubles. }\end{array}$ & 1748 \\
\hline 16 & $\begin{array}{l}\text { Electricity costs for the drive of pumps for pumping cooling water } \\
\text { and condensate drainage of flue gases, regulated drive of smoke } \\
\text { pumps for the year of operation, thousand kWh (thousand rubles) }\end{array}$ & $771(848)$ \\
\hline 17 & $\begin{array}{l}\text { Economic effect of the implementation of the considered technical } \\
\text { solution } \\
\text { (p. } 11-\text { p. } 13+\text { p. } 15-\text { p. } 16), \text { thousand rubles }\end{array}$ & 9565 \\
\hline
\end{tabular}

To ensure the simple payback period of financial costs not more than 4-5 years, the maximum value of capital investments for the implementation of the technical solution under consideration for the considered working conditions should not exceed 38 - 48 million rubles.

\section{Conclusions}

1.The technical solution for the construction of an additional flue gas included in parallel to the existing boiler flues, with the placement of a recuperative heat exchanger in it to cool the flue gases below the dew point with the return of the cooled flue gases after the heat exchanger to the common gas flue of the boiler by using a chimney with an adjustable drive allows:

- to take out a zone of dangerous corrosion processes from the main existing gas flues of the boiler in the additional gas flue and the heat exchanger which shall be made of corrosionresistant materials (or are protected from corrosion by the corresponding anticorrosive coverings);

- exclude condensate of flue gases from the flue pipes of the power plant and ensure the flue gas temperature at the entrance to the chimney in accordance with RD 153-34.1-21.523-99 "The instruction on operation of reinforced concrete and brick pipes and flues on thermal power plants" not less than $1000 \mathrm{C}$ at any loading of the boiler, fuel composition, excess of air.

2.When implementing this technical solution, it is necessary to pre-develop a feasibility study for the correct assessment of the results of this solution, both positive (increase in efficiency due to a decrease in the temperature of the outgoing gases of boilers, obtaining additional income from the formation of condensate from flue gases, which after decarbonization can be returned to the station cycle) and negative (reduction in the share of heat generation due to the unloading of the heat removal of turbines, increase of electric own needs of power plant for pumping of cooling water on again mounted heat exchangers and branch of the formed condensate, costs of the regulated electric drive of the additional smoke exhauster of branch of flue gases on heat exchangers and return of the cooled flue gases in gas flues of the boiler).

\section{References}

1. Statement of the Government of Russian Federation № 1339, 07.12.2015.

2. E. Ibragimov, J. Scientific horizons, 3, P. 71 to 83, (2017).

3. Modernization of air heat exchanger RVP-54 boiler TGM-84 " B " at Kazan CHPP-1. Catalog of new equipment and technologies introduced in JSC "Generating company", [Online], available at: http://www1.tatgencom.ru/netcat_files/gencom/ expo2011/download/heating_engineer_13.pdf (Accessed 25 Sep 2018).

4. Typical energy characteristics of the boiler TGMP-114 in the combustion of natural gas TX-34-70-001-83, Soyuztekhenergo, M., Russia (1983) 
5. Nomenclature catalog Taganrog boiler plant date (2018), [Online], available at: http://www.tkz.su/customers/KK Nomenklaturni_catalog_preview.pdf (Accessed 25 Sep. 2018).

6. RD 153-34.1-21.523-99. Instructions for use of reinforced concrete and brick chimneys and flues in thermal power plants, (2000), ORGRES, M, Russia.

7. Yu. Sosnin and E. Bukharkin, High-efficiency gas water heaters contact, 4nd ed., Stroyizdat, M, Russia (1988)

8. A. Malikov Tatneft and energy saving resources, [Online], available at: https://rg.ru/2017/03/23/reg-pfo/tatneft-raskryla-sekrety-resursosberezheniia.html (Accessed 25 Sep. 2018). (2017)

9. Thermal calculation of boilers (standard method), 3nd ed., NPO CKTI, SPb. Russia. (1998)

10. RD 34.08.552-95. Methodical instructions on drawing up the report of power plant and joint-stock company of power and electrification about thermal efficiency of the equipment, (1995), ORGRES, M, Russia. 